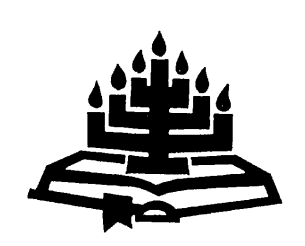

\title{
Die erediensgebed en MIV/vigs
}

\author{
B.J. de Klerk \\ Skool vir Kerkwetenskappe \\ Potchefstroomse Universiteit vir $\mathrm{CHO}$ \\ POTCHEFSTROOM \\ E-pos: kwsbjdk@puknet.puk.ac.za
}

\begin{abstract}
Prayers in the worship service and HIV/Aids

It seems as if most churches are still - to a great extent - not seriously involved in the problems of the HIV/Aids pandemic, and that prayers in the worship service for people suffering from HIV/Aids are few or even totally absent. The extent of the pandemic is overwhelming, especially in Sub-Saharan Africa. The needs and the suffering of Aids patients in terms of the physical, psychological and social aspects of their lives are likewise radical. The stigmatisation of Aids is far-reaching among all the population groups and forms the source of degradation and loneliness experienced by HIV-positive people. Churches should thus bring this suffering before God in prayer. Prayer is a communicative action in the worship service, but it is much more than communication; it is communion with the almighty God. In his communion with people praying to Him, God gives them strength to bring about a change of heart and attitude towards those for whom they are praying. Guidelines are suggested for focusing on HIV/Aids too in the elements of doxology, thanksgiving, humbling and prayers during the worship service. The conclusion arrived at implies that occasional worship-service prayers focusing on HIV/Aids can have a definite influence on the congregation's attitude towards, their involvement with, and their active care for people suffering from HIV/Aids.
\end{abstract}

\section{Opsomming \\ Die erediensgebed en MIV/vigs}

Dit blyk dat die meeste kerke nog baie onbetrokke is by die MIV/vigs-pandemie en dat daar min of glad nie vir mense wat aan MIV/vigs ly, in die erediens gebid word nie. Die omvang van die pandemie is geweldig, veral in Afrika suid van die Sahara. Die nood 
en lyding van Vigs-pasiënte met betrekking tot die fisiese, psigiese en sosiale aspekte van hulle lewens is net so radikaal. Die stigmatisering van vigs is verreikend onder al die bevolkingsgroepe en dit veroorsaak vernederende pyn en eensaamheid by mense wat MIVpositief is. Daarom moet die kerke hierdie leed voor God bring. Gebed is ' $n$ kommunikatiewe handeling in die erediens, maar dit is meer as blote kommunikasie: dit is gemeenskap met die almagtige God. Deur die krag wat Hy in sy gemeenskap met die bidders uitoefen, word hulle gesindheid en optrede verander teenoor diegene vir wie hulle bid. Riglyne word voorgestel om in lofprysing, danksegging, verootmoediging en voorbidding óók te konsentreer op MIV/vigs. Die gevolgtrekking is dat erediensgebede wat soms ook op die MIV/vigs -krisis toegespits word, 'n definitiewe uitwerking kan hê op die gemeente se gesindheid teenoor, betrokkenheid by en aktiewe versorging van mense wat aan MIV/vigs ly.

\section{Inleiding}

Daar is kerke in Suid-Afrika wat vir meer as 'n dekade intensiewe werk doen ten opsigte van MIV/vigs, maar die grootste persentasie kerke is nog nie betrokke nie (Wittenberg, 1994:61; Pick, 2002:15). Kerke is dikwels swak ingelig oor die probleem, deel maklik in die stigmatisering daarvan en is in baie gevalle nie toegerus om pastorale hulp aan MIVgeïnfekteerdes en hulle naasbestaandes te gee nie (Pacanet, 2003:3). Daar is analiste wat beweer dat kerke in Suid-Afrika meestal van vigs praat as "punishment for sexual sin" en daarom oor MIV/vigs swyg (Preston-Whyte, 1999:145).

Oor die kerk se verantwoordelikheid ten opsigte van MIV/vigs is heelwat gepubliseer (vgl. onder andere Louw, 1988:66-79; Louw, 1990:37-50; Hart, 1993:109-116; Somlai et. al., 1997:415-426; WCC Study Document, 2000; Benn, 2002:3-18; Pick, 2002). Wat egter nie in genoemde boeke en artikels gehanteer word nie is die uitwerking wat erediensgebede mag hê op die gemeente se gesindheid teenoor, betrokkenheid by en aktiewe versorging van mense wat MIV/vigs -geïnfekteerd is. Die vraag wat in hierdie artikel behandel word, is dus of erediensgebede, wat ook van tyd tot tyd ernstig konsentreer op aspekte rondom MIV/vigs, 'n uitwerking op die gemeente se betrokkenheid daarby sou kon hê.

Die volgende aspekte word daarom ondersoek: 'n empiriese oorsig oor kerklike betrokkenheid by MIV/vigs, die nood van mense wat MIV/vigsgeïnfekteerd is, die krag van erediensgebede wat fokus op onder andere MIV/vigs en enkele riglyne vir sulke gebede. 


\section{Empiriese oorsig oor 'n aantal kerke se betrokkenheid by MIV/vigs}

Die doel van empiriese ondersoek is altyd om kennis te genereer wat dit moontlik sal maak om 'n huidige onbevredigende situasie na 'n meer aanvaarbare te verander (Heitink, 1999:223-225). Volgens Heitink (1999: 229-231) bestaan daar verskeie metodes van empiriese navorsing: beskrywend, verkennend en die toets van hipoteses. In hierdie deel van die artikel word die volgende verkennend ondersoek:

- die persepsies van drie verskillende groepe oor die kerk se roeping ten opsigte van MIV/vigs;

- of gebede waarin op die MIV/vigs -probleem gekonsentreer word, wel voorkom.

Die drie ondersoekgroepe is die volgende:

- Tien Tswanasprekende Gereformeerde predikante met wie in November 2002 kwalitatiewe onderhoude gevoer is aan die hand van vraelyste (Tswanasprekende predikante, 2002),

- $40 \%$ van die Sinodegangers (Gereformeerde predikante en ouderlinge uit al die streke van Suid-Afrika) wat kwantitatiewe vraelyste tydens die Sinode van Januarie 2003 voltooi het (Sinodegangers, 2003) en

- 250 kerkleiers van verskeie kerke uit ses van die nege provinsies in Suid-Afrika wat kwantitatiewe vraelyste en verslae van sestien werksgroepe in 'n werkswinkel oor Kerk en MIV/vigs op 13 en 14 Maart 2003 voltooi het (Werkswinkel, 2003).

Slegs dié vrae wat in die gesprekke en vraelyste betrekking het op hierdie ondersoek, is vir die doeleindes van hierdie artikel in aanmerking geneem.

Uit die onderhoude met die Tswanasprekende predikante blyk dat al tien oortuig is dat daar MIV-positiewe mense in hulle gemeentes is, maar net een van die predikante weet wat die identiteit van die persone is (Tswanasprekende predikante, 2002, punt 3). Hoewel al tien predikante oortuig is dat die siekte in elke gemeente tot heelwat sterftes lei, is die feit dat die persoon vigs gehad het, nie aan enige van die kerkleiers bekendgemaak nie (Tswanasprekende predikante, 2002, punt 2). Daar word ook nie in die eredienste op enige wyse vir mense wat MIV-positief is, gebid nie (Tswanasprekende predikante, 2002, punt 5 en 7). Uit die vraelyste blyk dat Sinodegangers meen dat $60 \%$ van die gemeenskap en $56 \%$ van die gemeente onbetrokke is by MIV/vigs: dus apaties, negatief, 
onverskillig en harteloos is. $20 \%$ van die gemeenskap en $23 \%$ van die gemeente is positief ingestel teenoor die implikasies van die probleem, is behulpsaam en beskou mense wat MIV-positief is as medesondaars. Meer as 50\% van die Sinodegangers wat die vraelys voltooi het, dui aan dat die gemeente deur inligting, kennis en toerusting betrokke gekry moet word by MIV/vigs. Geeneen van die toetspersone noem dat die erediensgebede (of gebede oor die algemeen) die krag het om lidmate te motiveer om mense met MIV/vigs by te staan nie (Sinodegangers, 2003). Uit die vraelyste wat die 250 deelnemers aan die Werkswinkel by die aanvang van die byeenkoms voltooi het, en uit die verslae van die werksgroepe blyk dat $25 \%$ van die deelnemers uit gemeentes kom waar programme aktief geloods word ter voorkoming van infeksie, die versorging van vigs-pasiënte en pastorale hulp aan hulle en hulle naasbestaandes. In hierdie gemeentes word gereeld vir die problematiek van MIV/vigs in sy verskeie fasette gebid. In $75 \%$ van die gevalle is kerke onbetrokke, ook wat voorbidding betref (Werkswinkel, 2003).

Uit hierdie gegewens blyk twee sake duidelik: eerstens dat dit noodsaaklik is dat die bestaande onbetrokkenheid van kerke verander moet word. Kerke kan nie die standpunt inneem van: Dit is nie ons probleem nie. Daarom hoef ons nie iets daaraan te doen nie! Tweedens is dit duidelik dat gebed die uitwerking op sommige kerke het dat hulle 'n positiewe gesindheid ontwikkel om by die dilemma van MIV/vigs betrokke te wees.

\section{Die omvang en nood van MIV/vigs}

Die omvang en nood van MIV/vigs is so radikaal dat kerke daardeur opgeroep word om hulle liefdesdiens in Christus na te kom teenoor mense wat geïnfekteer en geaffekteer is. Sedert 1981 tot aan die einde van 2002 is wêreldwyd reeds 71 miljoen geïnfekteer met die virus. Daar het 28 miljoen mense gesterf aan vigs, waarvan die grootste persentasie in Sub-Sahara-Afrika was. In 2002 is meer as 5 miljoen mense geïnfekteer en het meer as 3 miljoen as gevolg van die siekte gesterf. Aan die einde van 2002 was daar 42 miljoen mense wêreldwyd (byna 30 miljoen in Sub-Sahara-Afrika en byna 5 miljoen in Suid-Afrika) wat geïnfekteer was en wat dus binne agt tot twaalf jaar mag sterf. In SubSahara-Afrika is vigs die grootste oorsaak van dood onder die bevolking. Daar word voorspel dat as daar nie drastiese gedragsverandering plaasvind en geen teenmiddel gevind word nie, tussen 5 en 7 miljoen Suid-Afrikaners teen 2010 aan die siekte kan sterf. Tot 'n kwart van die mense tussen 20-64 (die werkerskorps van Suid-Afrika) kan teen 2010 deur vigs uitgewis word (bostaande statistiek verkry van UNAIDS, 2003). Dit is 'n siekte wat al die bevolkingsgroepe raak en kan nie meer as 'n Afrika-siekte geëtiketteer word nie. Van die geïnfekteerdes is $79 \%$ 
heteroseksueel (baie vroue is deur hulle eie mans wat ontrou is, geïnfekteer), $13 \%$ babas (by wie die virus van moeder tot kind oorgedra is), $7 \%$ homoseksueel en $1 \%$ MIV-positief deur bloedkontak (soos deur spuitnaalde, bloedoortapping en werkers in bloedbanke). Kinders waarvan die moeders (of ook vaders) aan vigs oorlede is, word as vigswesies getipeer en tans is daar byna 600,000 van hulle en die verwagting is dat dit in Suid-Afrika teen 2010 tot 1,95 miljoen wesies kan styg (Benn, 2002:3,4). Hierdie kinders word dikwels straatkinders, eindig as sekswerkers en ontwikkel gewoonlik hoërisikoverhoudings wat meebring dat die siekte deur hulle optrede verder versprei. In SuidAfrikaanse tronke is ongeveer $42 \%$ van die gevangenisbevolking MIVpositief en van die sterftes aan natuurlike oorsake is $95 \%$ MIV-verwant (HIV/AIDS News, 2003).

Hierdie ontstellende realiteit behoort tot ernstige smeking tot en voorbidding by God te lei. Die kerk het die roeping om vir die wêreld en sy nood by God in te tree. Statistiek is nie al wat 'n gemeente tot gebed sal bring nie, maar die nood en lyding van die vigs-pasiënt is net so radikaal. Daar is veral drie dimensies van lyding: die fisiese, die psigiese en die sosiale, en as dit gesamentlik funksioneer, is dit 'n geweldige traumatiese lyding (Wittenberg, 1994:61).

Vigs is 'n siekte wat met die intiemste komponente van die menslike bestaan geassosieer word. Dit is 'n siekte wat die liefdesverhouding binnedring en opnuut die plek en funksie van geslagsgemeenskap, intieme verkeer en liefkosing onder verdenking bring (Louw, 1988: 68).

Daar kan maklik 'n kommunikasiebreuk ontstaan tussen die pasiënt en sy omgewing: sy naasbestaandes kan hom/haar verwerp, die gemeenskap kan teen die persoon diskrimineer en vriende kan ongemaklik voel en kunsmatig optree. Skuldgevoelens word al erger namate liggaamskragte afneem en dit kan lei tot 'n soort ego-aggressie, 'n fataliteit en 'n woede teenoor die gemeenskap. Sommige pasiënte se emosionele nugterheid neem so af dat hulle redeneer: ek gaan nie alleen nie, ek gaan kyk hoeveel ander ek met my in hierdie doodloopstraat kan saamneem (Louw, 1990:45). Dit blyk dus dat daar 'n intense afwesigheid van hoop is, wat 'n uitwerking het op hulle verhouding met God (Kgosikwena, 2001:209).

Die fisiese pyn in die latere fases van die siekte is oorweldigend en die aantasting van die immuunstelsel kan uitloop op long-, spysverterings- of selfs breinsiektes wat bitter lyding meebring. Al die fases van ander terminale siekte kom ook by hierdie pasiënte voor, naamlik ontkenning, skok, woede, isolasie, depressie, onderhandeling met God, en moontlik 
dan daarna aanvaarding. In gevalle kom dit voor dat mense die laaste dae en ure eensaam, verbitterd en vol haat teenoor God op hulle sterfbed deurbring (Kgosikwena, 2001:210). Die feit dat dit dikwels 'n persoon in sy/haar jeug is wat ly, maak dit vir die huisgesin en uitgebreide familie baie traumaties, omdat so 'n persoon dikwels jong kinders in die sorg van bejaardes agterlaat en bejaardes ontneem word van tuissorg wanneer hulle dit werklik nodig het. Talle behoeftige huishoudings word verder in die ellende gedompel omdat dit gewoonlik die broodwinner is wat die eerste prooi van die gevreesde pandemie word (Pick, 2002:31).

Die grootste probleem is egter die stigma en verwerping wat met hierdie siekte gepaard gaan, die diskriminasie teen mense wat die siekte selfs binne die monogame huwelik opdoen, omdat die een eggenoot ontrou was (UNAIDS in Africa, 2001:1). Die omvang van die stigmatisering van vigs is groot onder alle bevolkingsgroepe. Dit blyk uit omvattende empiriese navorsing dat vigs met 'n losbandige lewenstyl verbind word en dat die verband tussen vigs en 'n permissiewe lewenstyl veroorsaak dat so 'n pasiënt onmiddellik 'n etiket kry (Louw, 1988:71). Vigs word verder as 'n besmettingsiekte beskou, uit vrees vermy baie mense sulke pasiënte en daarom kan vigs selfs die melaatsheid van die moderne eeu genoem word. Louw (1988:66) toon aan dat vigs selfs in gereformeerde kringe beskou word as 'n straf van God op die praktyk van homoseksualisme. Genoemde stigmatisering bring vir vroue en mans wat binne die monogame huwelik deur hulle huweliksmaat geïnfekteer is, vir kinders aan wie die virus by geboorte oorgedra is en vir MIV-positiewe mense wat die virus deur bloedoortapping opgedoen het, ontsaglike en vernederende pyn en eensaamheid. Daarom behoort die hart van elke gemeente in gebed na sulke mense uit te gaan.

\section{Die krag van die erediensgebed}

In die erediensgebed openbaar die gebede van die gemeente, kollektief in hulle ontmoeting met God in die gemeente, 'n gesprekskarakter (Lourens, 2000:6). Kommunikasie in die erediens, ook in gebede, geskied in 'n pastorale konteks wat gerig is op heling en genesing, en daarom kan die gemeente deur die kommunikasie tot aktiwiteit gebring word. Die doel van kommunikasie in die erediens is die ontmoeting van God met die gemeente, wat die ontmoeting van die gemeente met God en met mekaar moontlik maak (Vos \& Pieterse, 1997:24). Binne so 'n konteks kan dialoog ontwikkel in onderlinge begrip en 'n mate van konsensus oor baie dinge. Waar gelowiges in die erediens - in God se teenwoordigheid - God en mekaar ontmoet, kan houdings, persepsies en optredes verander, ook wanneer die krisis van MIV/vigs in die gebed gekommunikeer word. Dialoog is 'n proses wat soos 'n spiraal na bo beweeg op die weg van groter insig, meer groei, groter onderlinge begrip 
en meer betrokkenheid by mekaar en die persone en aangeleenthede wat in die gebed betrek word (Vos \& Pieterse, 1997:26). Gebed word ingedeel volgens die semantiese domein van kommunikasie (Du Rand, 1990:36). Ten opsigte van genoemde woordgroep kom Louw en Nida (1988:409) tot die volgende konklusie: "The most generic expression for prayer may simply be to speak to God". Wanneer vir iemand anders gebid word, tree die voorbidder as bemiddelaar op (vgl. byvoorbeeld Ef. $6: 18$ ) en betoon hy/sy liefde wat 'n uitwerking op die bidders se optrede kan hê.

Gebed is egter nie net kommunikasie nie, maar meer: gemeenskap met God (Louw, 2001:66), met die medebidders en met dié wat in die gebed aan God opgedra word. God stig communio en maak gebed sodoende moontlik. In sy almag en alomteenwoordigheid het God nie ons gebede nodig nie, "but he wants it, thanksgiving and intercession, as the entering of his creatures into his loving will, by which he created human light in his communication of himself" (Cullmann, 1995:143). Gelowiges bevind hulle deur die gebed in die sfeer van God se liefde en dit beteken dat God diegene liefhet vir wie ons bid, oneindig meer as wat ons hulle liefhet (Cullmann, 1995:143).

Dit gaan in die gebed vir die persoon wat MIV/vigs-geïnfekteerd is, soos vir alle mense, bo alles om die eer van God. Dit gaan dus nie bloot om die vra van effektiewe medikasie en die stuit van die verspreiding van die Ml-virus nie, maar dat die mag en eer van God erken sal word. Juis daarom is dit verkeerd om die gebed te misbruik om nie met God in gesprek te wees nie, maar om die gemeente deur gebede te probeer motiveer. Die Fariseërs wat hardop op straathoeke gebid het om mense te beïnvloed, is afstootlik vir die gelowige van vandag, maar die voorganger in die erediensgebed kan ook dieselfde sonde doen as hy/sy die gebed misbruik om die gemeente daardeur toe te spreek en selfs te probeer manipuleer (Cullmann, 1995:123). Die aard van die erediensgebed as kommunikatiewe handeling in die erediens is geleë in die hoorders se reaksie op die spreker. Lidmate in die erediens moet kan verstaan wat in die gebede gesê word (1 Kor. 14:15) om deelnemend te kan saambid, anders kan hulle nie instemmend verklaar dat hulle hulle daarmee vereenselwig of daaraan deelneem en daardeur tot aksie aangespoor word nie (Lourens, 2000:32).

Om vir MIV/vigs oor die algemeen en vir die geïnfekteerde mens in die besonder te bid, is iets van 'n ontbloting, omdat hierdie toestand vir die meeste mense 'n seksverwante siekte is. Seks is 'n onderwerp waaroor in kerke geswyg word en wat selfs in huishoudings vermy word. Gebed is juis 'n kanaal waardeur die bidders hulleself en hulle gemeenskap voor God kan ontbloot. Ontbloting is 'n pynlike proses en laat die mens 
weerloos, maar as die wonde van MIV/vigs hierdeur skoongemaak kan word, word die ontbloting 'n middel tot herstel. Hartstogtelike klagtes en sugte in gebede ruk ontredderde bidders (Ps. 77) en geloofsgemeenskappe (Ps. 74, 79 en 137) se wonde oop. Hierdeur word die angs en frustrasie, die moeite, nood en pyn van mense hoorbaar, al moet dit gelowiges in die erediens wees wat dit namens vigs-pasiënte buite die erediens uitspreek. Herstel, genesing en betrokkenheid kan dan by pasiënt en gemeente intree, omdat God as Geneesheer sy oë en hande op stukkende lewenswonde hou (Human, 2001:63). In sowel die liturgie as in die sosiale betrokkenheid van die kerk binne die samelewing kan die ontbloting in die gebed ' $n$ rol speel om verandering te bemiddel. Die kerk se kritiese betrokkenheid by MIV/vigs kan lidmate tot konkrete dade van vertroue, dank, belydenis en lof tot God aanmoedig. Dit kan ook die lydensomstandighede van MIV-positiewe mense en vigs-pasiënte in 'n nuwe lig stel: God se opgawe aan sy kerk aan die begin van die een-entwintigste eeu (Human, 2001:70).

Van Zyl (2001:380) sê die oorkoepelende doel van gebed is die eenwording van die gelowige met God en sy wil. In die Nuwe Testament is die Heilige Gees die gebedsmiddelaar wat die diepste roersel van ons denke deurgrond en dit in ooreenstemming bring met God se wil (Rom. $8: 26,27)$. Die krag van gebed blyk ook daarin dat God gebede in ag neem by die volvoering van sy oordele (Op. 8:3-4) en daarom bring gebede aksie by die bidders en by God. Gemeenskap met God beïnvloed die bidder (Louw, 2001:80). Hierdie beïnvloedingsgebeure moet egter nie as gebedsmanipulasie gesien word nie, want dit gaan nie bloot oor die behoeftes van die mens nie, maar oor die krag wat gemeenskap met God in die lewe van die bidders uitoefen. Die bidders se innerlike word in aanraking gebring met 'n objektiewe werklikheid: die heil in Christus as 'n aanduiding van 'n nuwe toestand van verlossing en bevryding. Die bidders word deur hierdie bevryding beweeg tot 'n uiting van die liefde wat uit die verlossing spruit. Dit kan die bidders genees van blindheid vir die leed van byvoorbeeld MIV-positiewe mense. Hiervan was Moses 'n voorbeeld. In die gloed van God se toorn oor die volk is die gevaar dat hulle sonde sal lei tot die uitwissing van die volk. Deur Moses se pleitrede word dit afgewend en sy gebed het ook 'n uitwerking op die volk: hulle verbind hulle om verder met God te lewe (vgl. Eks. 32:11-33:16; Smit, 1997:441).

Daar kan tot die volgende konklusie oor die krag van die (erediens) gebed gekom word: juis vanweë die aard van gebed as kommunikatiewe handeling in die erediens, ontwikkel begrip en betrokkenheid by die bidder vir mense en aangeleenthede waarvoor gebid word. Maar die gebed is meer as kommunikasie - dit is gemeenskap met die almagtige God wat deur die krag wat in sy gemeenskap met die bidders uitgeoefen 
word, hulle gesindheid en optrede teenoor diegene vir wie hulle bid, kan verander. Die gebedsinhoud mag nie misbruik word om die gemeente te probeer manipuleer nie. Wanneer die doel van die gebed egter is om God te eer sal dit die (saam)bidders in die erediens nie onaangeraak laat bly nie, maar tot aksie aanspoor. Omdat 'n gebed ontbloting is, ruk dit die wonde van onbetrokkenheid en apatie oop (ook teenoor die MIVpositiewe mens) wat in die gemeente mag wees en kan dit verandering in houding en gedrag by die gemeente bemiddel. In die erediensgebed word bidders deur gemeenskap met God met die verlossing en bevryding in Christus bekragtig. Die bidders word deur hierdie bevryding beweeg tot die uiting van liefde wat uit die verlossing voortspruit. Dit gaan dus oor die krag wat gemeenskap met God in die lewe van die bidder uitoefen. Gebed beskik oor die krag om bidders, deur die inwerking van die Heilige Gees, sensitief te maak vir die mense en sake waarvoor God geloof, gedank en gesmeek en waarvoor daar skuld bely word (Parrish, 1996:241).

\section{Riglyne vir erediensgebede wat fokus op MIV/vigs}

Omdat hierdie pademie so 'n radikale impak op die Suid-Afrikaanse samelewing het, behoort elke gemeente van tyd tot tyd in sy erediensgebede op die verskeidenheid fasette rondom MIV/vigs te konsentreer. Die kerke, as die liggaam van Christus, het immers die roeping om aan Christus se liefde konkrete gestalte te gee in die samelewing waarin hulle geplaas is. Dit beteken nie noodwendig dat in elke gebed of by elke samekoms van die gemeente MIV/vigs aan die orde moet kom nie, maar dit mag ook nie geïgnoreer word asof dit nie dié ernstigste vraagstuk is waarmee in Suid-Afrika geworstel word nie. In die gemeentebrief wat voor die diens verskaf word, of by wyse van mondelinge bekendstelling kan die nodige inligting gegee word wat dit vir elke deelnemer aan die erediens makliker sal maak om van harte saam te bid. Wanneer iemand wat MIV/vigs-geïnfekteer is, of 'n werker wat sulke persone bystaan en versorg, getuienis oor hierdie siekte lewer, sal dit ook bydra tot die saambid met die voorganger. Die gemeente kan ook lektuur of videomateriaal aan lidmate beskikbaar stel (Tihan, 2002:2,3).

Dit sou selfs (vanweë die radikale omvang van MIV/vigs), nie onvanpas wees, as kerke landswyd 'n dag van verootmoediging en gebed uitroep nie nadat die besef van die nood tot kerke uit alle bevolkingsgroepe deurgedring het nie. Daar is byvoorbeeld 7500 kerke in die VSA wat jaarliks 'n week van gebed hou vir alle aspekte wat die MIV/vigspandemie raak. Die gevolg van hierdie instelling oor die afgelope elf jaar is dat gemeentes meer bewus raak van die probleem en dat lidmate hulle gawes en talente gebruik om die verspreiding van MIV te keer en om uit te reik na dié wat ly as gevolg van vigs (Veenker, 2000:22, 23). 
Vir ware aanbidding is die vereiste dat dit Geesbepaald en Christusmatig moet wees - Christusmatig in die sin dat die aanbidding getrou moet wees aan dit wat in Christus geopenbaar is. Die gebedsingesteldheid moet volgens Johannes 4:23-24 in Gees en waarheid en met 'n kinderlike gesindheid geskied (Du Toit, 1994:273). Dit beteken verder opregte, onbaatsugtige Godgerigtheid, Godsvertroue en vergewensgesindheid. Ander riglyne vir aanbidding in die erediens sluit in eerbied en bewondering vir God (lofprysing) en dankbaarheid teenoor God (danksegging), sondebesef en berou (verootmoediging en skuldbelydenis), smeking wat selfs 'n klaaggebed kan wees, afhanklikheid en Christelike liefdesgesindheid (voorbidding; vgl. Du Toit, 1994:273). Langs hierdie weë word verdere riglyne gegee vir die erediensgebed, wat konsentreer op MIV/vigs.

\subsection{Lofprysing in die erediensgebed}

Lof kan beskou word as die erkenning van wie God is (sy deugde) en dank as erkenning vir wat God skenk en doen (sy dade). Lof is die hart van Bybelse gebede en lof kan getipeer word as die sentrale doel van alle gebed (O'Kennedy, 2000:543). God is vir die gelowige en ook vir mense wat MIV/vigs-geïnfekteerd is, die Heerser, die Koning oor siekte, dood en bose magte. Daar is talle mense wat MIV-positief is wat glo dat bose magte hierdie siekte deur towery oor hulle gebring het. God is die Geneesheer wat in Christus ook alle siektes op Hom geneem het en so die angel van lyding uit selfs MIV/vigs gehaal het. God is die Vertrooster van sterwendes en van naasbestaandes in rousmart wat voortvloei uit die geweldige aantal sterftes en begrafnisse wat tans as gevolg van vigs plaasvind. Aan God behoort alle mag en daarom kan Hy dié bekragtig wat nie meer verder kan of wil gaan nie. Hy is die Lewe, die Skenker van die nuwe lewe in Christus en daarom gee Hy ook die ewige lewe aan mense met MIV/vigs wat in Christus glo. God is die Skepper wat diep betrokke is by ons geskiedenis en ons huidige lyding. God is liefde en Hy buig Hom in liefde neer na gebroke mense en dié wat deur ander gestigmatiseer word (Kgosikwena, 2001:213). Vir hierdie eienskappe van God, wat inspeel op die lewe van MIV-positiewe mense, moet God geloof word.

\subsection{Danksegging in die erediensgebed}

In dankgebede word God gedank vir sy reddingsdade, sy hulp, beskerming en genadegawes (Human, 2001:61). God se reddingsdade trek saam in die lewe, sterwe, opstanding en voorspraak van sy Seun. Vigs is nie te radikaal vir die radikaliteit van die opgestane Christus nie. Christus se opstandingsoorwinning het ook die angel uit die dodelikheid van vigs gehaal. Die kerk beskik daarom oor 'n boodskap van hoop wat 
die radikaliteit van vigs in ooreenstemming met die radikaliteit van God se genade kan transendeer en transformeer (Louw, 1988:79). Hoop gee betekenis en verwys na God se voortdurende teenwoordigheid en ononderbroke versorging en bystand in die moeilikste omstandighede van die mens se lewe. Die dank oor God se dade gaan dus ook oor die ontferming wat Hy betoon het in die kruis van Jesus Christus. God is in sy goedheid altyd gereed om dit wat goed is, aan mense te gee, en die klimaks van sy gawes as vrug van die oorwinning van Christus oor die doodsmagte is die Heilige Gees. Die Gees sug saam met die lydende vigs-pasiënt en bring die onuitgesproke versugtinge van die persoon wat nie weet hoe en wat om te bid as gevolg van die nood en pyn van sy/haar siekte nie, in ooreenstemming met God se wil voor sy genadetroon. Die gemeente het dus in sy erediensgebede oorvloedige stof tot dankbaarheid, veral omdat gelowiges namens ander met vrymoedigheid na Hom kan gaan (Van Zyl, 2001:384), ook oor 'n siekte wat sommige mense as 'n besmettingsiekte beskou.

\subsection{Verootmoediging, skuldbelydenis en vergewing in die erediensgebed}

In die verootmoediging van 'n gemeente voor God is ' $n$ belangrike erkenning dat lidmate medesondaars is. Gemeentes moet ook die sonde van die gemeenskap, die sonde van die nasie op hulle neem. Jesaja bely nie net dat hy self sondig is nie, maar dat hy woon onder ' $n$ sondige volk (Jes. 6:5; vgl. ook Neh. 1:5-7). Die toorn van die Here kom oor alle sonde, ook die sonde van seksuele verhoudings wat nie volgens God se wil is nie. Daarom moet ook hierdie sonde deur die hele gemeente bely word. Daar is diegene wat MIV-positief is en wat steeds nie met die sonde van seks buite die huwelik gebreek het nie. Die bidders moet die Heilige Gees smeek om berou in diesulkes wakker te maak oor die sondige lewenstyl in die gemeente en in die gemeenskap. Uit die berou sal hartgrondige skuldbelydenis volg wat die voorganger in ootmoed en deur identifisering met ander sondaars behoort uit te spreek. Die Here beloof dat opregte skuldbelydenis deur vergewing gevolg sal word en daarom sal die bidders self onmiddellike vergiffenis ervaar en 'n nuwe verhouding met God word daardeur tot stand gebring (Human, 2001:61). Die hopeloosheid van die situasie rondom MIV/vigs kan nie losgemaak word van die sonde van die samelewing nie, al kan die siekte nie aan 'n spesifieke sonde gekoppel word nie. Enige gebed vir die land, die kontinent en die wêreld moet gedra word deur hartgrondige skuldbelydenis. Die Skrif leer egter ook dat daar tot die einde van die wêreld rampe, oorlog, siektes en hopelose situasies sal wees en selfs in intensiteit sal toeneem. Volharding in die geloof kan om hierdie rede nie gedra word deur 'n blote versugting dat die ellende van mense afgeweer 
moet word nie. Die gebed van verootmoediging moet ook die perspektief open op die verwagting dat vanuit die ellende die koninkryk sal aanbreek en die volle vrede en geregtigheid en heerlikheid in eskatologiese sin sal bring (Smit, 1997:448).

Die radikale aspek van MIV/vigs bestaan hierin dat dit die mens op verdoemende wyse van sy nietigheid, verganklikheid en bedorwenheid bewus gemaak het en hom/haar daarom tot ootmoed kan bring. Hierdie angskomponent van MIV/vigs met sy verwoestende effek dwing 'n gemeente wat sy naaste liefhet, om sy eie verganklikheid beter te verstaan en om nederig voor God te bly. Die gemeente kan in sy gebed identifiseer met die magteloosheid van onsekerheid wat hierdie virus by mense bring, sowel as met die dodelike konsekwensies van vigs (Louw, 1988:71). Juis daarom is dit nie onvanpas om self en namens mense wat MIV-geïnfekteer is, opreg met God te worstel nie. Die gebede wat ernstig soek na God se wil, gaan met baie worsteling gepaard. God kan in sy almag soms sy plan verander, soos by Hiskia (2 Kon. 20:1-6) en by Jona (Jona 3:3-10), maar soms ook nie, soos Jesus se gebed in Getsemane dat die lydensbeker moet verbygaan (Mark. 14:36,39) en by Paulus se gebed oor die doring in die vlees (2 Kor. 12:1-10). Daar is geen teenstrydigheid tussen God se soewereine heerskappy en sy openheid om na die gebede van die gemeente te luister nie (Van Zyl, 2001:387). Paulus het die grense van wat hy kon vra - die wil van God, spesifiek omtrent lyding - nie byvoorbaat geken nie; hy moes dit biddend leer. Dit sou ook van toepassing kan wees op 'n gemeente se worsteling om die betekenis van lyding as gevolg van MIV/vigs te leer ken. Die Christelike gebede wat in die Nuwe Testament aangetref word, is algaande gevorm deur 'n teologie van die kruis, waar gebedsverhoring nie soseer bestaan in die toestaan van versoeke nie, maar in die openbaring van God se genade en krag in swaarkry (Van Zyl, 2001:389).

Die beskuldiging word dikwels uit kerkkringe gemaak dat MIV/vigs God se straf is, en dan spesifiek op die praktyk van homoseksualisme. Dan word aangevoer dat die Skrif self soms 'n verband tussen sonde en siekte lê - soos in Psalm 38:4-5 en in Psalm 41:5. In die worsteling met God moet egter gesoek word na 'n uitweg wat die MIV-positiewe persoon nie met 'n nimmereindigende skuldkompleks laat nie. Die pasiënt sal in sy siektesituasie van sonde bewus raak en moet dit eerlik voor God bely.

Wie egter probeer om agter elke siekte 'n persoonlike sonde te soek ten einde die siekte kousaal-oorsaaklik met God en sy toorn in verband te bring, beland in die moeilikheid. Jesus wys self so ' $n$ kousaal-oorsaaklike verklaringsmodel af (Joh. 9:3) (Louw, 1988:76). 
Die vigs-pasiënt hoef dus nie sy/haar skuld eers te bely voor God die sonde vergewe nie. Genade beteken onvoorwaardelike liefde en algehele kwytskelding van skuld, want die vergiffenis vind plaas op grond van die middelaarswerk van Christus. Dit moet in die erediensgebed aan die orde kom as pleitrede in die worsteling met God op grond van God se belofte aan die sondaar.

Job se worsteling met God gee riglyne vir die gemeente se worsteling in sy erediensgebede oor MIV/vigs. Job praat nie soos sy vriende oor God nie, maar met God, want hy weet dat alleen 'n ontmoeting en gemeenskap met God sal hom in staat stel om sy onverstaanbare lyding te kan dra. Worsteling en gelowige protes is vir Job 'n vorm om sy hoop en geloof in God tot uitdrukking te bring - ten spyte van sy ervaring wat die teenoorgestelde hiervan is. Daarom kan hy uitroep: "My Verlosser leef". Dikwels is daar geen oplossing vir die probleem van lyding nie, behalwe deur persoonlike gemeenskap met God wat mense kan verander (Wittenberg, 1994:66). 'n Groot versoeking vir 'n gemeente is om oor God en sy oordeel in abstrakte terme te praat en so die nood, lyding en wanhoop van die vigs-pasiënt uit die oog te verloor. Maar wanneer regstreeks met God in gebed gemeenskap gehou word, kan verrassende antwoorde na vore kom. Job worstel in die taal van klaaggebed en selfs beskuldiging teen God, en dit gee juis uitdrukking aan sy pyn, maar ook sy hoop op God. Wat die gemeente moet weet, is dat God se teenwoordigheid nie net gedemonstreer word in sy almag om die pasiënt te genees nie, maar ook dat die pasiënt geestelik genees kan word. Dit kan in sy/haar belydenis, soos by Job, weerklank vind: "Ek het van $U$ gehoor, nou het my oë U gesien". God kan die pasiënt wat aan vigs sterf, tot die besef laat kom dat God se krag ook in menslike swakheid volbring word.

\subsection{Voorbidding in die erediensgebed}

Voorbidding handel oor die intree ter wille van 'n ander en is in die Bybel soms vir 'n individu, of vir die volk, of vir die hele gemeente of vir die heidene/nasies (Jer. 14:1-15:2; Joh. 17:1-26; Rom. 15:30; O’Kennedy, 2000:544). Die bidders vra om God se ingrype in 'n situasie en pleit om redding in 'n krisis. In hierdie noodsituasie word die uitsigloosheid beklemtoon en die bidders se onvermoë om iets daaraan te doen. Ook word die bidder se afhanklikheid van God voor Hom bely en God se reddingskrag word veronderstel (Human, 2001:64).

In hierdie deel van die artikel gaan dit veral oor voorbidding vir die gemeente, vir die persoon wat MIV/vigs-geïnfekteerd is en vir die families van geïnfekteerdes. 


\section{- Voorbidding vir die gemeente}

Bidders in die erediens moet onder andere voorbidding doen dat God 'n gesindheidsverandering teenoor die MIV/vigs-pandemie by die gemeente sal teweegbring. Uit die aangehaalde lektuur en empiriese resultate is dit duidelik dat te veel gemeentes nog apaties en selfs veroordelend en onbetrokke teenoor die MIV/vigs-probleem van die land staan. Vigs moet by die gemeente nederigheid en 'n gees van medelye (invoeling in die lewe van persone wat MIV-geïnfekteerd is) bring. In die erediensgebed moet gebid word om 'n oop oog vir mense wat worstel met skuld en daardeur van God en medemens vervreem word, en vir die genade om aan ' $n$ bediening van versoening gestalte te gee. In die gebed moet gevra word vir die gesindheid van Christus wat leer dat ander hoër as jyself geag moet word en dat gelowiges - soos Christus - bereid sal wees om aan die "melaatses" van vandag te raak en hulle in te skakel (Kgosikwena, 2001:214). Die inskakeling van 'n MIV-geïnfekteerde persoon in die gemeentelewe sal 'n helende uitwerking hê op sowel die gemeente as die geïnfekteerde persoon (vgl. Somlai, et al., 1997:417). Die voorbidding vir die gemeente moet daarvoor pleit dat die koinonia in die gemeente sodanig mag wees dat dit die geïnfekteerde kan help om die kommunikasiebreuk met sy omgewing te heel en aan hom/haar die gevoel van identiteit en menswaardigheid te kan teruggee, sodat die vrese en woede van die pasiënt binne 'n gesindheid van liefde gehanteer kan word.

In die gemeente moet ook gebid word dat die gemeente en die samelewing 'n Bybelse siening van seksualiteit sal handhaaf of ontwikkel. Die kerk as gemeenskap van gelowiges het nie altyd openlike en eerlike gesprekke oor seksualiteit aangemoedig nie en die kwessie van menslike seksualiteit het in die meeste ekumeniese (kerklike) gesprekke oor die MIV/vigs-pandemie die minste aandag gekry (Pick, 2002:53). Seksualiteit benodig 'n vaste struktuur wat op permanensie, verantwoordelikheid en liefdestrou gebaseer is (Louw, 1988:78). Monogame heteroseksualiteit met die aksent op duursaamheid en verantwoordelikheid is die vertrekpunt. Hierdie waardes kan nie afgedwing word deur skuldgevoelens en vrees by mense op te wek nie, maar alleen deur 'n nuwe verbintenis en toewyding aan God en gehoorsaamheid aan die norme wat die Skrif neerlê (Louw, 1990:49). Die erediensgebed moet ook pleit dat God die gemeente en veral gemeenskappe se kulturele persepsies van seksualiteit sal verander: dat God bekering sal bring omdat hierdie siekte dikwels deur losbandige seksuele omgang versprei word en dat Hy die mites by mense oor die voorkoming en verspreiding van MIV/vigs deur Bybelse beginsels sal vervang (Benn, 2002:5). Daar bestaan byvoorbeeld die mite dat MIV deur toordery oorgedra word en dat MIV niks met seksualiteit te make het nie. 


\section{- Voorbidding vir mense wat MIV/vigs-geïnfekteerd is}

Hierdie tipe gebed spruit uit die feit dat mense wat MIV-geïnfekteerd is, dikwels beskou word as individue wat hulle beginsels oorboord gegooi het. Die gebed van die gemeente moet wees dat sulke persone se identiteit en swak selfbeeld herstel word, want hulle bestaan is ook in God gegrond, hulle is geskape as beeld van God, en Christus se versoening is genoegsaam sodat so 'n persoon deur die geloof in Christus kan lewe en Christus in die persoon. Daarom moet die gemeente bid dat persepsies in die gemeente en die samelewing sal verander en dat mense wat MIV/vigs-geïnfekteerd is, nie gestigmatiseer en verwerp word nie. Die psigologiese nood van die MIV-positiewe mens kan ontsaglik intens wees en vrees vir vervreemding is meestal teenwoordig. Die persoon se kommunikasie met medemense word dikwels verminder en selfs afgebreek weens die stigmatisering. Daarom moet gebid word vir 'n oop verhouding waarin pasiënte vrymoedigheid sal hê om hulle vrese en troos met lede van die gemeente te deel. In 'n aangrypende artikel vertel Hart (1993:111-114) van 'n gemeente in die VSA waar die predikant aan vigs gesterf het en hoe 'n deel van die genesingsproses van die gemeente was om in erediensgebede te bid dat hulle met mekaar in ootmoed oor die siekte, sy omvang en radikale nood kan praat.

Dit is noodsaaklik dat die gemeente sal bid dat hulle self én ander praktiese liefdesdiens aan MIV/vigs-geïnfekteerde mense verleen. Vigs is nie 'n onhanteerbare probleem wat gemeentes kan vermy nie, maar 'n geleentheid wat God skep om liefde aan siekes en so aan Christus te betoon (vgl. Matt. 25:34-40). Deur Christus se onvoorwaardelike liefde aan dié wat ly en sterf te bedien, kan God se genade deur die optrede van sy kerk gemanifesteer word. Hierdie praktiese liefdesdiens beteken versorging van die pasiënt by sy/haar huis deur kos te verskaf, vervoer na mediese klinieke te bied en geleentheid vir ontspanning te skep. Verder is persoonlike higiëniese sorg en geldelike hulp om opbouende voedsel en vitamines te bekom, wyses waarop kerke hulle roeping teenoor vigs-pasiënte kan nakom. Alleen gebed sal gemeentes se oë hiervoor oophou en hulle inspireer om prakties by MIV-positiewe mense betrokke te raak en te bly. 'n Diensgroep om die gemeente te adviseer, te begelei en as voorbeeld op te tree, kan waardevol wees.

Erediensgebede kan van tyd tot tyd ook voorbidding vir die pasiënt en gemeente inhou om lyding te verstaan, te hanteer en te verwerk. Soos by ander terminale siektes gaan die persoon wat MIV-geïnfekteerd is deur verskillende fases. Louw (1990:46, 47; vgl. Kgosikwena, 2001: 201209) noem die vier fases: die impakfase, die regressiefase, die internaliseringsfase en die rekonstruksiefase. Die gebede moet rekening hou 
met dit wat die pasiënt in elk van hierdie fases beleef en benodig. Die impakfase word gekenmerk deur skok, ontkenning, ernstige angs en hulpeloosheid. Die basiese nood is aanvaarding, begrip, liefde en veral die kuns om te luister. Knutson (1979:20) druk dit so uit:

The willingness to listen is the willingness to remove the risk for others so that they may receive the gospel at the deepest level of life. It is a willingness which requires time, effort, energy, and above all, the love which tunes in to another person's situation.

In die regressiefase begin die realiteit van die probleem deurbreek en ervaar die persoon sommige van hierdie emosies: woede, isolasie, passiewe gevoelloosheid en daarom soek die persoon ontsnappingsmeganismes en is hy/sy nie bereid om tot aksie oor te gaan nie. Ondersteuning in hierdie fase behels onder andere vriendskap en bewusmaking dat die persoon deel is van die liefdesgemeenskap. In die internaliseringsfase werk die persoon deur die langtermynkonsekwensies van die siekte en ondergaan daardeur 'n rouproses oor alles wat hy/sy besig is en finaliter gaan verloor. Hierdie emosies kan lei tot depressie en onderhandeling met God om uit die situasie te kan kom. In hierdie fase is dit belangrik om die persoon te help om God se onvoorwaardelike liefde te ontdek en die besef dat hy/sy 'n persoon met ewigheidswaarde is te bevestig. In die rekonstruksiefase kan die persoon besluite neem, die toekoms beplan en selfs nuwe doelwitte ontwikkel om die tyd wat nog oor is, positief te benut. Hier kan die begeleiding toespits om die persoon te motiveer om oor God se krag in die lydingsproses te getuig. Gebede vir die lydende vigs-pasiënt moet met hierdie fases rekening hou.

\section{- Gebed vir die families van geïnfekteerdes}

Pasiënte kan nooit geïsoleerd van 'n gesin en vriendekring gesien word nie. Die gesin treur oor die bedreiging van die dood wat hulle geliefde, moontlik 'n seun of 'n dogter, broer of suster, in die gesig staar. Die gesinslede worstel om tot berusting te kom oor die gestigmatiseerde siekte en die uiteindelike dood van die geliefde. Die familie gaan ook deur skuldgevoelens omdat hulle familielid vanweë sy/haar eie toedoen of lewenswyse met die Ml-virus geïnfekteer is en omdat so 'n persoon deur die breë gemeenskap verwerp word (Pick, 2002:85). Binne die Afrika-kultuur is die gesinsverlies van ' $n$ jongmens in die wonderlikste tyd van sy/haar lewe 'n traumatiese ervaring, want dan het die ouers nie meer iemand wat vir hulle in hulle ouderdom kan sorg nie. By die dood van 'n vigs-pasiënt reageer mense met 'n gedempte houding en dikwels vertel hulle liewer 'n leuen oor die oorsaak van die dood as om te erken dat die persoon vigs gehad het. Die begrafnis is dikwels 'n geleentheid met onderdrukte vraagtekens en die hele familie voel skaam oor die 
skeptiese houding van die sosiale omgewing (Louw, 1988:78). In hierdie benarde omstandighede is voorbidding vir die familie dat God uitkoms sal gee van die uiterste belang.

\section{Samevatting}

Uit die tersaaklike vakliteratuur en empiriese gegewens blyk dit dat die meeste kerke nog baie onbetrokke is, maar dat erediensgebede 'n beduidende rol speel waar enkele kerke aktief programme loods ten opsigte van MIV/vigs. Die pandemie is van geweldige omvang in veral Sub-Sahara-Afrika en die nood en lyding van vigs-pasiënte ten opsigte van die fisiese, psigiese en sosiale aspekte daarvan is net so radikaal. Die stigmatisering van vigs is groot onder al die bevolkingsgroepe en dit bring vernederende pyn en eensaamheid by mense wat MIV-positief is. Daarom moet kerke hierdie leed voor God bring. Gebed beskik oor die krag om die gemeente sensitief te maak en tot aksie aan te spoor teenoor persone en sake waarvoor tot God gebid word. Gebed is 'n kommunikatiewe handeling in die erediens, maar dit is meer as kommunikasie: dit is gemeenskap met die almagtige God. Deur die krag wat Hy in sy gemeenskap met die bidders uitoefen, word hulle gesindheid en optrede teenoor diegene vir wie hulle bid, verander. Dit is die uitwerking wat die gebed op bidders kan hê, ook wanneer hulle vir mense bid wat MIV/vigs-geïnfekteerd is.

In die lofprysingsdeel van die erediensgebed moet God vir sy eienskappe, wat ook sal inspeel op die bestaan van mense wat met die gevolge van MIV/vigs lewe, geloof word. Die danksegging moet God se liefdesdade noem waarmee Hy Hom met stukkende mense bemoei en waardeur Christus met sy opstanding die angel uit die dodelikheid van vigs gehaal het. In sy verootmoediging, skuldbelydenis en ontvang van vergewing bring die gemeente sy eie en die gemeenskap se sonde voor God, ook die sonde waar die infeksie met die Ml-virus deur seks buite die monogame huwelik veroorsaak is. Worsteling met God - ook omdat die pasiënt magteloos, weerloos en moedeloos voel - is ook geoorloof. Vergewing beteken onvoorwaardelike liefde en algehele kwytskelding van skuld en moet as sodanig met die geloof toegeëien word. Die voorbidding in die erediensgebed vra dat die gemeente se gesindheid en optrede teenoor mense met die Ml-virus positief sal wees en dat die Bybelse waardes oor seksualiteit weer hul regmatige plek sal kry. Vir die MIV-positiewe mens en die vigs-pasiënt moet voorbidding gedoen word vir die verskillende vorme en fases van lyding, vir 'n nuwe verhouding met God, die gemeente en die gemeenskap. Omdat families en gesinne ook geteister word deur pyn, lyding, rousmart, stigmatisering en skuldgevoelens, moet die voorbidding ook die uitkoms vir families en gesinne in hulle krisis betrek. 
Die finale konklusie waartoe gekom kan word, is dat die erediensgebede, wat ook soms op die MIV/vigs-krisis gekonsentreer is, 'n definitiewe uitwerking kan hê op die gemeente se gesindheid teenoor, betrokkenheid by en aktiewe versorging van mense wat leef met die gevolge van MIV/vigs.

\section{Bibliografie}

BENN, C. 2002. The influence of cultural and religious frameworks on the future course of the HIV/Aids pandemic. Journal of Theology for Southern Africa, 113:3-18.

CULLMANN, O. 1995. Prayer in the New Testament. With answers from the New Testament to today's questions. London : SCM.

DU RAND, J.A. 1990. Enkele kernmomente oor gebed in die Nuwe Testament. Ned Geref Teologiese Tydskrif, 31(1):35-46.

DU TOIT, A.B. 1994. Liggaamstaal in gebed: 'n Nuwe-Testamentiese perspektief. Skrif en Kerk, 15(2):264-279.

HART, C.W. 1993. "Our minister died of AIDS": Pastoral care of a congregation in crisis. The Journal of Pastoral Care, 47(2):109-116.

HEITINK, G. 1999. Practical Theology: history, theory, action domains. Translated by Reinder Bruinsma. Grand Rapids : Eerdmans.

HIV/AIDS News. 2003. Prison Aids deaths up by 750\%. Number 20, Feb. 19.

HUMAN, D.J. 2001. Gebed: 'n proses wat verandering bemiddel. Verbum et Ecclesia, 22(1):58-71.

KGOSIKWENA, K.B. 2001. Pastoral care and the dying process of people living with HIV/AIDS. Speaking of God in a crisis. Missionalia, 29(2):200-219.

KNUTSON, G. 1979. Ministry to inactives: a manual for establishing a listening witness to inactive members. Minneapolis : Augsburg.

LOURENS, P.K. 2000. Gebed as kommunikatiewe handeling in die erediens. Potchefstroom : PU vir CHO. (Th.M.-verhandeling.)

LOUW, J.P. \& NIDA, E.A. 1988. Greek- English lexicon of the New Testament based on semantic domains. Goodwood, Cape : United Bible Societies.

LOUW, D.J. 1988. Vigs, die radikale siekte met die radikale uitdaging aan pastorale bediening. Ned Geref Teologiese Tydskrif, 29(1):66-79.

LOUW, D.J. 1990. Ministering and counselling the person with Aids. Journal of Theology for Southern Africa, 71:37-50.

LOUW, D.J. 2001. 'n Teologie van gebed: Kommunikasie as communio en dank. Acta Theologia, 2:65-84.

O'KENNEDY, D.F. 2000. Gebed in die Ou en Nuwe Testament: 'n vergelykende studie. In die Skriflig, 34(4):535-555.

PACANET. 2003. 2003-2004 Draft funding proposal. Gaborone : Southern Africa HIV/AIDS prevention intervention strategies.

PARRISH, V.S. 1996. Praying as reformed Christians. Encounter, 57(3):231-243.

PICK, S. 2002. MIV/vigs - ons grootste uitdaging nog! Die pad vorentoe vir die kerk in Suid-Afrika. Wellington : Lux Verbi.BM.

PRESTON-WHYTE, E. 1999. Reproductive health and the condom dilemma: identifying situational barriers to HIV protection in South Africa. (In Caldwell, et al., eds. Resistance to behavioral change to reduce HIV/Aids infection in predominantly heterosexual epidemics in Third Word countries. Canberra : Health Transition Centre. p. 139-155.) 
SINODEGANGERS. 2003. 75 vraelyste tydens die Sinode van die Gereformeerde Kerke in Suid-Afrika voltooi. Januarie 2003. Die vraelyste en verwerkings is by die outeur van die artikel beskikbaar.

SMIT, E.J. 1997. Die voorkoms en betekenis van gebede in die Ou Testament. In die Skriflig, 31(4):437-451.

SOMLAI, A.M. et al. 1997. The response of religious congregations to the spiritual needs of people living with HIV/Aids. The Journal of Pastoral Care, 51(4):415427.

TIHAN. 2002. Ideas for congregational HIV/Aids ministries. Unpublished newsletter. June.

TSWANASPREKENDE PREDIKANTE. 2002. Tien vraelyste en aantekeninge van gesprekke met tien Tswanasprekende Gereformeerde predikante uit die NoordWes-provinsie op 25 en 26 November 2002. Die vraelyste, verwerkings en aantekeninge oor gesprekke is by die outeur van die artikel beskikbaar.

UNAIDS. 2003. Global fund to fight Aids, Tuberculosis and Malaria; Kaiser Family Foundation. Centers for disease control and prevention. US Bureau of the Cencus. http://www.kaisernetwork.org/static/spotlight hivaids factsataglance,cfm [Date of access: 19 Feb. 2003].

UNAIDS IN AFRICA. 2001. Plan of action: The ecumenical response to HIV/Aids in Africa. Nairobi, Kenya, 25-28 November 2001.

VAN ZYL, H.C. 2001. Drie probleemareas in gebed: 'n perspektief vanuit die Nuwe Testament. Hervormde Teologiese Studies, 57(1 \& 2):379-396.

VEENKER, J. 2000. African American focus on AIDS outreach. Christianity Today, 44(5):22-23.

VOS, C.J.A. \& PIETERSE, H.J.C. 1997. Hoe lieflik is u woning. Pretoria : Raad vir Geesteswetenskaplike Navorsing.

WCC STUDY DOCUMENT. 2000. Facing AIDS, the challenge, the churches' response. Geneva : WCC Publications.

WERKSWINKEL. 2003. 250 vraelyste en verslae van 16 werksgroepe van die Werkswinkel oor Kerk en MIV/vigs. Die vraelyste, verwerkings en verslae is by die outeur van die artikel beskikbaar.

WITTENBERG, G.H. 1994. Counselling Aids patients. Job as paradigm. Journal of Theology for Southern Africa, 88:61-68.

\section{Kernbegrippe:}

erediensgebed

kommunikatiewe handeling

MIV/vigs

stigmatisering

Key concepts:

communicative action

HIV/Aids

prayers in the worship service

stigmatisation 
